Article

\title{
Illicit Money in Contemporary Islamic Ethics
}

\author{
Abdessamad Belhaj \\ Catholic University of Louvain, 1348 Louvain-la-Neuve, Belgium; abdessamad.belhaj@uclouvain.be
}

Received: 10 July 2018; Accepted: 23 July 2018; Published: 25 July 2018

\begin{abstract}
This paper discusses the question of the acquisition and the use of illicit money, māl harām from the perspective of Islamic ethics. It first addresses five fatwas by Markaz al-fatwa on different cases of illicit money. Subsequently, the paper engages in an ethical analysis of the responses and the arguments that Markaz al-fatwa provides to justify certain positions on the issue of illicit money. The discussion ends with an investigation of the difficulties of legalistic Islamic ethics in adapting to the Western contexts.
\end{abstract}

Keywords: illicit money; Islamic ethics; Markaz al-fatwā; necessity; capacity

\section{Introduction}

From the perspective of Islamic ethics, illicit money, māl harām, is "any money which Islamic law forbids to acquire or to use either because it is harmful or bad property in itself such as carrion or wine, or because it is forbidden for an external reason, for example in the way it was acquired from its legitimate owner without his/her authorisation, through usurpation, or obtaining it through unacceptable ways in Islamic law even with the consent of the owner such as bank interest or bribery" (Al-Bāz and al-Ashqar 1998, pp. 40-44). This definition that is provided by al-Bāz and al-Ashqar, two major contemporary Muslim jurists and references on Islamic law and ethics from Jordan, raises two main questions: if illicit money is defined by Islamic law, then what responsibility should be assigned to individuals in specific ethical situations? Second, what should be considered as illicit money in a liminal context, non-governed by Islamic law; is it the social ethics of the given territory or Islamic law?

As is seen in the definition provided by al-Bāz and al-Ashqar, there is an implicit link between the use of illicit money and injustice since acquiring money illegally harms a particular individual or group or state. Thinking in terms of Islamic ethics of maqūṣid (higher objectives of Islamic law), one can assert that forbidding illicit money assures social justice. To ask the opposite question: could one acquire or use illicit money to assure social justice, in some cases? Sofos and Tsagarousianou have shown that Muslims in Europe display strong narratives of contestation and claims of injustice, adopting "injustice frames", in which they articulate and share their grievances (Sofos and Tsagarousianou 2013, pp. 118-27). In such context, whereby agents perceive themselves as victims of social injustice, how would they react in a concrete situation involving illicit money?

Despite the claims of Muslim jurists, Islamic ethics could be ambiguous on some concrete ethical situations, mixing principism, divine commands, and pragmatism. In transactions, Muslim lawyers and law sources often diverge, and they do not provide explicit regulations except in few cases. Moreover, the authority of official lawyers is contested and fragmented, and while some Muslims prefer flexible lawyers, others, especially young traditionalists, lean towards radical lawyers.

As a matter of fact, it is less complicated to discuss illicit money in a context in which Islamic law, Islamic ethics, and social ethics overlap in Muslim societies. In the latter, family, society, and state enforce certain Islamic norms about illicit money, whereby one can hear the injunction "this is illicit money!" from cradle to grave. However, outside this context, ethical choices, unsupported by the above mentioned structures, becomes challenging. Muslim legal authorities, which assume the role of 
updating/producing Islamic law and ethics today, face recurrent questions on allowing or forbidding the smuggling activities, laundering money, stolen money, etc.

Of particular concern to Muslim ethics of money is the appropriate conduct that an agent should adopt in non-Islamic societies. For example, migration provides a context in which ethical choices are intricate to be made with regard to illicit money because migration entails, in many cases, vulnerability to the local circumstances and the absence of a Muslim watchful eye. In the current mobile and world economy, illicit money has become a central issue for Muslim ethical agents as well. Some of the important questions include individual and simple behaviour about acquiring or using illicit money, especially for believers worrying about their moral conscience. Concerns are rising regarding illicit and "dirty" money in both the Muslim world and the West as it is related to corruption and underdevelopment.

To date, few works of juristic literature have been published in Arabic on illicit money, māl harām and to the best of my knowledge, no critical research was conducted in the Western academia on this topic. The available juristic studies set to frame the following major issues: a summary of what classical figh $^{1}$ says about illicit money, an attempt to cover new major issues, such as money laundry (Al-Bāz and al-Ashqar 1998), and the ways to get rid of illicit money (Al-'Anzī 2014) and repent ('Umar 2001), or to prevent recourse to illicit money (Hawwāsh 2011). Thus, the new figh of illicit money discusses macro-illicit money in main Islamic institutions, such as zakāt. It barely says anything about concrete ethical contemporary situations, not to mention situations of mobility, migration, or liminality. It leaves this field to the fatwa process whereby agents request the opinion of Muslim clerics about concrete situations either through direct contact or through Islamic websites. The five cases I analyse here come from Markaz al-fatwā (Islamweb.com) based in Qatar, and one of the most popular online fatwa provider in Arabic, consulted by thousands of readers.

This paper has been divided into three parts. The first part introduces and comments briefly on five fatwas discussing the use of illicit money as issued by Markaz al-fatwa . The second part examines the ethical arguments of Markaz al-fatwā and Muslim ethics of necessity/need and capacity, and whether they justify the use of illicit money or not, especially in non-Muslim lands. Finally, the third part intends to determine the extent to which Islamic ethics allows for a permissive distributive justice, setting to investigate the limits of moral obligation towards non-Muslims according to legalistic Muslim ethics.

\section{Five Fatwas on the Use of Illicit Money Issued by Markaz Al-Fatwā}

Markaz al-fatwa is a website of fatwas that is run by Islamweb.com, and supervised by the Administration of Da'wa and Religious Guidance at the Ministry of Endowments and Islamic Affairs in Qatar. The Markaz is a team of Sunni Muslim jurists, which collaborate to research and edit fatwas, without referring to a particular school, following the wasatiyya method. ${ }^{2}$

\subsection{Ruling on Lying for Asylum in a Non-Islamic Country}

Question: I live in Russia and my visa is over. After the visa expired, I asked for asylum here, and got it by bribing. After a year my asylum ended. Now I want to get asylum again, but this time I will not pay a bribe. I will be asked some questions and I will lie. They will ask whether I work in Russia, and I will say that I live with my friends and that my brother sends me money to live here, and they will ask where does my family live in Syria and whether they live in places of danger. I want to work in Russian factories and these factories allow work only for those who have papers or systematic asylum. In this case, can I lie to them to

\footnotetext{
For a scholarly study of the free rider problem in figh and Abbasid finance policies, See (Mårtensson 2011).

al-Ta'rîf bi-markaz al-fatwā.

http:// fatwa.islamweb.net/fatwa/index.php?page=aboutfatwa.
} 
get asylum to be able to work in Russia and my salary be licit (haläl)? What about what I did in the past when I got asylum with a bribe? Was my salary during that period licit?

Response: If your work is permissible, and you do what you have to do for the salary you take, then the salary is haläl. As for lying and bribery, in principle they are illicit, unless there is a significant need for your stay in this country. Then, this case is ruled by "the necessity makes the illicit licit". Fatwa 322597 by Markaz al-fatwā (Islamweb). ${ }^{3}$

This atomistic response of Markaz al-fatwā is typical of juristic thinking. It refuses to deal with the ethical concerns of the agent about bribing and lying. Instead, it establishes lines between what is permissible and what is not in Islamic law. The salary is permissible because it pays a permissible work, while one cannot, from an ethical perspective, separate a salary that is obtained as a consequence of bribery, ignoring the ethical concern of the questioner. Again, the Markaz al-fatwa discards the ethical concerns and insists on the Islamic legal rule, necessity makes the illicit licit.

\subsection{Ruling on Cheating Non-Muslim Countries to Take Aid from Them and Not Paying the Bills}

Question: Some religious scholars ruled that the countries of Europe are infidel countries, and it is permissible to circumvent them to take aid from them, or to avoid the payment of electricity bills. My friend used to help her husband in this matter, but she felt that this was illicit, harām and asked her husband to return the money to the state. He refused and said that this is permissible, and my friend repented and became pious, but she does not have any personal money to repay this stolen money, and all the money is in her husband's hands. The question is: Does God accept her repentance?

Response: If this wife stopped doing this sin, and no longer helps her husband in this matter, and regretted what she did, and resolved not to return, her repentance, God willing, is acceptable. The husband has to return the money to the state and the wife has to continue giving him advice. Fatwa 276136, 2014, by Markaz al-fatwā (Islamweb). ${ }^{4}$

Markaz al-fatwa breaks down the ethical situation into that of the wife and that of the husband, while the question concerns only the wife. In particular, the question seems to be that of the wife's moral conscience as she regrets what she did. The response does not delve into the acceptability of such repentance $(t a w b a)$ rather than building on it as an Islamic ethical principle, offering a moral leeway to the wife. The answer avoids reflecting on the fact that she also stole money from the state, helping her husband, does not mention the possibility to refer to the authorities about the situation-in which case, she will also be responsible, not to mention her husband. The response discards, here, the moral responsibility of the wife (and the husband) towards the non-Muslim state, and even in terms of Islamic law, obligations towards non-Muslim laws should be respected, and their property should not be damaged or thwarted or harmed (Müssig 2015, p. 140). Instead, the response loosely asks the husband to return the money and the wife to advice him. The response ambiguously takes no stand against the religious scholars who allow for stealing money from infidel countries, and does not either want to adopt a radical opposing view, by forbidding such an attitude, or vehemently discouraging the husband from stealing money, knowing that from the perspective of Islamic ethics, it is an evil act, and punishable in the herein and the hereafter.

3 Hukm al-kadhib min ajl al-hușūl 'alā al-lujū fì balad ghayr Islāmī.

http:/ / fatwa.islamweb.net/fatwa/index.php?page=showfatwa\&Option=FatwaId\&Id=322597\& fromCat=966.

4 Hukm al-tah̄āyul 'alā al-duwal al-käfira li-akhdh ma'ūna minhum wa-'adam daf' fawātì̀r al-khadamāt.

http:/ / fatwa.islamweb.net/fatwa/index.php?page=showfatwa\&Option=FatwaId\&Id=276136\&fromCat=966. 


\subsection{The Duty of Those Who Used the Money of the European Countries and Receive the Aid They Do Not Deserve}

Question: I lived in a European country for about 15 years. I had access to a number of credit cards, each with a financial limit that could be spent or withdrawn from the card in cash through the ATM. Once, I realized that this was an infidel country and there was nothing wrong with making use of the possible funds of each card especially that the banks will not lose anything, because it will deduct the amount of unpaid debts from the taxes owed to the government and only the government is to lose, after I justified this idea to withdraw all the funds allowed in each card with the intention of non-payment, I got the amount of approximately 276,000 pounds, then I moved to work in a neighbouring European country. Response: It is obligatory for this person to repent to God from that, and from his dealings with this illicit money of bank interest, and to seek to restore the rights of people to the extent of his ability. If he can not return the amount of money, then he should give it to the poor or to the public interest. And if he cannot pay back the money, Allah does not charge a soul except [with that within] its capacity. Fatwa 220222, 2013, by Markaz al-fatwā (Islamweb). ${ }^{5}$

Markaz al-fatwā has recourse, here, again to the ethical principal of tawba, which implies regretting the misdeeds and a determination to avoid them. Implicitly, the questioner indicates that, now that he lives in a different country, he does not steal anymore and by asking the question he regrets his deeds. He is already in the mode of tawba, feeling guilty. The response, somehow, is emphatic not about stealing money, stressing rather that the stolen money was in fact bank interest, because bank cards are using bank interest, and as such, are harām. The fatwa, in a general tone of classical figh, requires reparation, which the questioner does not expect or realistically envision. He resides in another country, and for him, what he did previously is a matter of moral conscience not of reparation.

The response gives him other options that he obviously cannot fulfil either, such as giving 276,000 pounds to the poor or to public interest. Then, the fatwa uses the capacity argument according to which an individual is only responsible within his/her capacities. I shall go back to this argument later. Suffices here to say that this ruling does not look at the Western context, in which prison could be an option for being unable to repair financially the damage an individual did to his/her society. Markaz al-fatwā again ignores the argument of the questioner that one can steal money in an infidel country. Since Islamic law does not allow for stealing money from non-Muslims, anywhere, it could have been important ethically to report it, since this is a recurrent argument, and stems from an ethical appreciation of one's status in a non-Muslim country, and of considering wrongly Europeans as people at war with Muslims, muḥ̄ribūn (Al-Bahnasāwī 2012, p. 66). ${ }^{6}$

\subsection{Can the Husband Travel with His Pregnant Wife to Give Birth in a European Country to Benefit from the} Financial Aid?

Question: I live in Algeria and my wife and I want her to give birth in France for the financial aid during and after pregnancy, is there anything wrong with that in terms of religion?

Response: If your intention is that you go with your wife to the infidel country to get some material benefits, this is permissible if the conditions of the residence in the countries of infidels are fulfilled, namely that you can practice your religion. However, the worldly

5 Wājib man ta'arrada li-awmāl al-duwal al-urūbiyya wa taqādā musā'adāt lā yastahiqquhā.

http:/ / fatwa.islamweb.net/fatwa/index.php?page=showfatwa\&Option=FatwaId\&Id=220222.

6 Sālim al-Bahnasāwī, the Egyptian Muslim jurist, commenting on some radical fatwas, states that "considering the property of non-Muslims as licit is not only theft, but a claim to legislate together with God, giving fatwas that make illicit things licit, and he who does so, is an apostate" (Al-Bahnasāwī 2012, p. 66). 
interests are not as important as one's practice of religion. It is better for you and your wife to stay in your country anyway. Fatwa 172745,2012 , by Markaz al-fatwa (Islamweb). ${ }^{7}$

One can note, at the beginning of the answer, how the Markaz al-fatwa a takes the idea of an infidel country for a premise, whilst it leads to some peculiar ethical conclusions. It does not give any consideration for the law or the ethics of living in non-Muslim countries. Yet, practicing one's religion implies displaying honest ethics in a non-Muslim country. The answer remarkably illustrates the tendency among Muslim clerics today to be scholastic about Islamic law rather than ethically interpreting law in accordance with particular moral dilemma.

It is also noteworthy how the response breaks down the elements of the ethical situation at stake here (can I steal French public money?) into separate elements, answering each differently. In particular, the Markaz al-fatwa agnores the intention of the questioner in stealing money from the French state, rephrasing the question into that of getting some material benefits in an infidel country. By premising the question on living in an infidel country and assuring the practice of religion, the response concludes by safely calling the questioner to stay at home. The strategy again is to answer another question not one asked by the questioner. The moral dilemma of the questioner was not about the probable difficulties in practicing religion, but about profiting from an aid without being entitled to it. Shifting from one concern to another only indirectly related one could be a strategy to avoid answering the question and directly blaming the questioner for his bad intentions. It could simply be that the Markaz al-fatwa is reasoning by blocking the pretexts, sadd al-dhara $\vec{a} i^{\prime}$, which consists in closing the licit gate for illicit aims: travelling to an infidel country in itself is licit, but because it implies, inevitably, hardship in practicing religion, one should rather stay safely in his Muslim country. It is worth to notice that the answer concludes with an advice, and, again no straightforward condemnation of dishonest behaviour in a non-Muslim country.

\subsection{Ruling on Smuggling People to Europe to Obtain Humanitarian Asylum}

Question: What is the Islamic ruling about smuggling people into Europe and who are not in danger, even helping them with little money, or sometimes he smuggles a family with no money, to obtain humanitarian asylum in Europe? Sometimes he takes an amount of money that is not comparable to what other smugglers ask for?

Response: If it is intended to smuggle people into a country they are not allowed in to enter, this is prohibited because of the risks that these individuals will be exposed to the dangers, and the pursuits that may end in their drowning, or arresting and humiliating them. But if those countries allow them to enter, and you help them to travel to the land of infidels this is different and depends on different people and conditions. If you know that travel is permissible, there is no problem with the permissibility of helping them travel. Fatwa 265426, 2014, by Markaz al-fatwā (Islamweb). ${ }^{8}$

While smuggling as such should be a predicament for Islamic ethics, ${ }^{9}$ Markaz al-fatwa divides it into smuggling into countries with restrictions on travel and those without, allowing for it in the latter case. Markaz al-fatwō's reasoning displays a bit of consequentialism: if smuggling leads safely to the desired destination, then there should be no problem. Again, the "land of infidels" seems to be a recurrent category of ethics, knowing that Markaz al-fatwa $\bar{a}$ is an Islamic moderate website, and does

7 Hal li-l-zawj an yusāfir bi-imra'atih li-tada'a hamlahā fì balad urūbbì li-yastafìd min al-musā'adāt.

http:/ / fatwa.islamweb.net/fatwa/index.php?page=showfatwa\&Option=FatwaId\&Id=172745\&fromCat=966.

$8 \quad H u k m$ tahrīb al-ashkhāṣ ilā bilād Urūbbā li-l-husṣul 'alā al-lujü al-insānī.

http:/ / fatwa.islamweb.net/fatwa/index.php?page=showfatwa\&Option=FatwaId\&Id=265426.

9 Dār al-iftā' in Egypt made it clear recently that "the participation or assistance in the smuggling of goods is illegal and prohibited in Islamic law".

Tahrīb al-badä $i^{\prime}$

http:/ / www.dar-alifta.org/ar/ViewFatwa.aspx?ID=13238\&LangID=1. 
not endorse radical Islamic ideology. The ambiguity of this type of Islamic ethics lies not only in its atomisation of the ethical situation into pieces, but also in making a crime, such as smuggling a matter of context. This ambiguity also lies in its rephrasing of smuggling as "helping them travel".

Moreover, the Markaz al-fatwa does not ask here the question, if travel were permissible to these countries, why would a person need a smuggler? No reflection is made on the fact that some families are not refugees i.e., fleeing from danger, neither on the problematic of terming a paid act as "help". Therefore, we can assume that the fatwa supports the questioner's quest for legitimacy as a smuggler, as it considers smuggling as help, which the questioner insisted to be his role.

\section{Arguments for the Use of Illicit Money: An Ethical Analysis}

The five fatwas were supported by three main arguments: the infidel lands, the necessity and the capacity arguments. In the following, we suggest to critically examine each of these arguments.

\subsection{The Argument from Infidel Lands}

This argument justifies some questioners' actions and most responses by the Markaz al-fatwa as well. With regard to the Muslim questioners, the argument could be formulated, as follows: since the lands of the infidels are not governed by Islamic law, some illicit things might be licit, since the goods of the infidels are not forbidden in the first place. In the Muslim law of war, this argument could be valid during war between Muslims and non-Muslims. However, this legal tradition is not at work anymore, at least since the 19th century. Besides, European or Western countries, are either at peace with Muslims or have signed treaties with them, according to which all property of non-Muslims are forbidden by the force of Islamic law. Although jihadists use this argument to steal property from non-Muslims, the scholarly tradition in all Muslim schools of law makes it clear that the jihadists are wrong in considering European countries as being at war with Muslims. Thus, the debate stems from whether Europeans are considered at war or not with Muslims. If someone adopts the first stance, like jihadists, Islamic law of war allows for taking the property of Europeans, and if one embraces the latter position, then, their property is forbidden.

Markaz al-fatwo also uses the argument from infidel lands either to treat these lands as permitting exceptional solutions, or to associate them with material benefits. This seems to be echoing the association made by some questioners between infidel lands and the use of illicit money. That is to say, infidel lands are a "potential space for sin". By perceiving the West as a land of material benefits and lack of ethics, questioners and respondents indirectly construct permissive ethics in non-Muslims societies. This perception was challenged by some Muslim jurists, especially those that are promoting the emergence of minority figh in the West, such as Ṭāhā Jābir al-'Alwānī (a Sunni jurist from Iraq who lived in the USA) who considers the category of land of infidels to be superfluous and restrictive (Al-Alwani 2003, p. 28).

\subsection{The Argument from Necessity}

The Markaz al-fatwa used the argument of darūra, necessity permitting the questioners options otherwise they are considered illicit. Although in the later terminology of ușül al-figh there is a difference between necessity, darūra and need, hāja, whereby the former implies situations of extreme importance for one's own survival, while the latter indicates needs of a normal life, they are used interchangeably in today's modern Islamic ethics. So does Markaz al-fatwā, which takes necessity to be a need. Anyway, staying in a European country is not a necessity, and not even a need. The questioners also have recourse to this argument believing their case to be that of an extreme need, requesting exceptions or "favours" or solutions from Islamic clerics. It is observed that these questioners misrepresent wants as necessity or need.

It is, therefore, of particular importance to clarify the notion of need in terms of Islamic ethics, in order to avoid further ambiguity. A recent study by Abdelilah Hajjy (2014) argues that, in Islamic ethics, there is a correlation between the mission of man on earth (by virtue of divine command), needs, 
and justice. Those needs that ought to be satisfied in accordance with the divine mission and justice are fundamental needs called kafäf (needs of subsistence) and necessary needs called kifāya (needs of sufficiency). These two types of needs could be reached, roughly, by the minimum income or allowance, which provides an individual with housing and food. Anything beyond is called commodity needs, which put the agent in the mode of wastefulness, isrāf (Hajjy 2014, pp. 109-25). Thus, by virtue of Islamic ethics, an individual cannot justify its desires, which are of the latter category, as needs. A prevailing consumerist culture, in the Muslim world as well as in Europe, could be one of the factors some people misrepresent their wants as needs.

\subsection{The Argument from Capacity}

We have seen that Markaz al-fatwa $\bar{a}$ used the argument twice from capacity (fatwas 2 and 3). The most evident case is fatwa number 3 when it asserts that if the questioner "cannot pay back the money, Allah does not charge a soul except [with that within] its capacity". ${ }^{10}$ The context of this verse 23:64 is rather that of believers who obey Allah, are eager to make the good deeds, while Allah does not impose any hardship on them nor he would harm them, indicating their blissful fate according to the divine justice in the hereafter. This context does not concern transactions nor is it related to Islamic law, but to the subjects of faith and soteriology. It argues, indirectly, against the disbelievers who might claim that divine commands are hard to fulfil, and therefore, it is beyond their capacity as creatures to obey Allah.

There is a real risk, as observed in daily affairs, that an agent would use its limited capacity, which is a fact for every human being, to justify the acquisition and use of illicit money, refusing to assume the responsibility of its act, thereof. More concretely, in a migratory context, an individual might, most probably, suffer from limits to its capacity, especially in terms of finances. A limited social capital is inherent to the migratory status, and could easily be a justification for illegal activity. By mobilising this argument, the Markaz al-fatwā could be, willingly or unwillingly, promoting a permissive ethics of money, and could be promoting a form of "moral laundry". Assuming that any individual who engages in illicit money knows the costs and limits of its capacity, and the limits of its capacity cannot be considered as an exit. It makes an integral part of the crime, and it should be punished accordingly the same as capacity is responsible in Islamic law, for financial or other types of crime.

\section{Legalistic Muslim Ethics and the Limits of Moral Obligation towards Non-Muslims}

Perhaps the main limitation of the current legalistic Muslim ethics, as illustrated by the Markaz al-fatw $\bar{a}$ with the collaboration of the questioners, could be its reliance on traditionalist authority. Legalistic Muslim ethics, although being a synthesis of pragmatism, principism, and ethics of divine commandments, bestows upon Muslim jurists an authority on matters and contexts that they can barely understand, restricted by their traditionalist legal reasoning. These jurists consider the norm not to be good in itself or because it leads to the happiness of the greatest number of people, but only because a tradition has stated it, independently from its context and purpose. This legalistic ethics is also an ethics of model, that of the previous generations of Muslims, some of whom engaged in conflictual relations with non-Muslims. This kind of legalistic thinking might lead some Western Islamic circles, as Andrew March has argued, to believe that, "this being the Abode of War, the relation to non-Muslims is one of war and the situation of Muslims one of jihād, non-Western goods and property are licit as booty, it is permissible to file false claims for social assistance and it is not necessary to pay taxes" (March 2009, p. 43).

Disengaging ethics from the juristic tradition could be an exit from its limits. Islamic ethics can draw on a multitude of resources as an alternative to legalistic thinking today. For example, among all of the good characters promoted by Islamic ethics, sincerity, ikhlās sis crucial. Sincerity

10 Wājib man ta'arrada li-awmāl al-duwal al-urūbiyya wa taqādā musā'adāt lā yastahiqquhā.

http:/ / fatwa.islamweb.net/fatwa/index.php?page=showfatwa\&Option=FatwaId\&Id=220222. 
is the prerequisite to all beliefs and rituals. In belief, ikhlạs is synonymous with tawhīd, which is the belief in the unity of God. In addition, one must be sincere in one's speech, in commerce, in promises, and so on. The abundance of Qur'anic verses and prophetic traditions on sincerity ought to be understood in this ethical context, while its opposites, deceit, hypocrisy, false testimony, and lies have been associated with the pagan Arab society, and are highly criticized. That said, the notion of $i k h l a \bar{s}$ should be de-traditionalised as well, as it has been also used in the modern times to promote traditionalist Islamic ethics. ${ }^{11}$ A greater focus on ikhlās as sincerity-cum-trust building could produce more constructive relations between Muslims and non-Muslims (as illustrated by the case of a Syrian migrant who found and returned 150,000 euros). ${ }^{12}$

\section{Concluding Remarks}

This study has found that the Markaz al-fatwō's ethical discourse encourages a permissive ethics of illicit money in migratory contexts. More precisely, while Markaz al-fatwa forbids, in principle, illicit money, it is permissive in certain ethical situations, which it characterises as necessary or difficult or occurring in the infidel lands. Such ethical discourse could be satisfactory for agents looking for moral laundry. Some Muslim individuals take the migratory context as a justification for their individual interests or projects. One of the significant findings to emerge from this study is that permissiveness occurs as result of misrepresenting desires or wants as needs and/or the West as a land of material benefits. Ultimately, such ethical reasoning could justify free-riding and predator behaviour.

The insights that are gained from this study suggest that legalistic Muslim ethics suffer from major limitations, especially in terms of how they perceive the relations Muslim should consider with non-Muslims, and their attitudes with regard to money and property in the West. By sticking to the traditionalist arguments of necessity, capacity, and the infidel lands, it falls short to think ethics in context, and to insist on the moral responsibility of Muslims living in the West. Notwithstanding these limitations, the study suggests that a reconstruction of Muslim ethics of money on the notion of sincerity, $i k h l a ̄ s ̣$ could be a possible solution. Sincerity-cum-trust building could produce more positive relations between Muslims and non-Muslims.

Funding: This research received no external funding.

Conflicts of Interest: The author declares no conflict of interest.

\section{References}

Al-Alwani, Taha Jabir. 2003. Towards a Figh for Minorities: Some Basic Reflections. London and Washington, DC: The International Institute of Islamic Thought.

Al-'Anzī, 'Azīz b. Farḥān. 2014. Khulāșat al-kalām fì al-takhalluṣ min al-māl al-harām. Riyad: Dar al-Ṣumay'î.

Al-Bahnasāwī, Sālim. 2012. Qawā'id al-ta'āmul ma'a ghayr al-Muslimīn. Cairo: Dār al-Nashr lil-Jāmi’āt.

Al-Bāz, 'Abbās Aḥmad Muḥammad, and 'Umar Sulaymān al-Ashqar. 1998. Ahkām al-māl al-ḥarām wa-ḍawābit al-intifā̄' wa-l-tasarruf bi-hi fĩ al-figh al-Islāmī. Amman: Dār al-Nafā'is.

Hajjy, Abdelilah. 2014. L'éthique économique en Islam au prisme du concept de besoin. Éthique et Économique 11: $109-25$.

11 Largely dependent on the works of Ibn Abī al-Dunyā (d. 894) and Abū Hāmid al-Gazzālī (d. 1111) whose perspectives put forward an ascetic ethics of sincerity, grounded in traditionalism, oriented towards God and the hereafter, while little preoccupied with its society.

al-Gazzālī's text, probably the most extensive and accessible Islamic text on ikhlās is the source of many Muslim authors today, and available in English:

Abū Hāāmid al-Gazzālī, On Intention, Sincerity and Truthfulness (Kitāb al-niyya wa'l-ikhlāṣ wa'l-ṣidq): Book XXXVII of The Revival of the Religious Sciences (Ihy $\bar{a}^{\prime}$ ' ulüm al-dīn), Translated with an introduction and notes by Anthony F. Shaker, Cambridge: The Islamic Texts Society, 2013.

12 German town hails Syrian refugee 'hero' for turning in $€ 150,000$.

https:/ /www.theguardian.com/world/2016/jun/28/minden-german-town-hails-syrian-refugee-hero-for-turning-ineuros. 
Hawwāsh, Muḥammad. 2011. Al-Tadābīr al-wāqiya min al-māl al-ḥarām. Al-Iskandariyya: Maktabat al-Wafā̄ al-Qānūniyya.

March, Andrew F. 2009. Sources of Moral Obligation to non-Muslims in the "Jurisprudence of Muslim Minorities" (Fiqh al-aqalliyyāt) Discourse. Islamic Law and Society 16: 34-94. [CrossRef]

Mårtensson, Ulrika. 2011. "It's the Economy, Stupid": Al-Tabarī's Analysis of the Free Rider Problem in the Abbāsid Caliphate. Journal of the Economic and Social History of the Orient 54: 203-38. [CrossRef]

Müssig, Stephanie. 2015. Muslims' Day-to-Day Handling of Property and the Adherence to Islamic Norms. A Systematic Review of Studies for Western Europe. Journal of Muslims in Europe 4: 137-73. [CrossRef]

Sofos, Spyros A., and Roza Tsagarousianou. 2013. Islam in Europe: Public Spaces and Civic Networks. Hampshire: Palgrave Macmillan.

Umar, Muhammad 'Abd al-Halīm, ed. 2001. Al-Ḥalqa al-niqāshiyya al-thāniya 'ashra hawla al-tawba min al-māl al-ḥarām. Cairo: Markaz Ṣāliḥ Kāmil lil-Iqtiṣād al-Islāmī.

(C) 2018 by the author. Licensee MDPI, Basel, Switzerland. This article is an open access article distributed under the terms and conditions of the Creative Commons Attribution (CC BY) license (http:/ / creativecommons.org/licenses/by/4.0/). 